\title{
Penerapan Model Fan-N-Pick dan Inside-Outside Circle untuk Meningkatkan Keterampilan Sosial dan Hasil Belajar Siswa Kelas IV Sekolah Dasar
}

\author{
Anita Nurgufriani ${ }^{1}$, Budi Eko Soetjipto ${ }^{2}$, Mohammad Zainuddin ${ }^{3}$ \\ ${ }^{1}$ Pendidikan Dasar-Universitas Negeri Malang \\ ${ }^{2}$ Pendidikan Ekonomi-Universitas Negeri Malang \\ ${ }^{3}$ Keguruan Sekolah Dasar dan Prasekolah-Univeristas Negeri Malang
}

\begin{tabular}{l}
\hline INFO ARTIKEL \\
\hline Riwayat Artikel: \\
Diterima: $13-05-2019$ \\
Disetujui: $14-12-2019$ \\
\hline
\end{tabular}

\section{Kata kunci:}

Fan-N-Pick;

inside-outside circle;

social skills;

learning outcomes;

Fan-N-Pick;

inside-outside circle;

keterampilan sosial;

hasil belajar

\begin{abstract}
The purpose of the study is to describe the application of the model FNP and IOC to improve the social skills and the learning outcomes of student class IV SDN 3 Besuki. Type of this research was PTK that includes two cycles. Research was conducted at SDN 3 Besuki, the subjectof this research is the students of class IV SDN 3 Besuki amounted to 32 people. Data collection: observation, interview, test, questionnaire, and documentation. The techniques of data analysis: reduction, data presentation and conclusion. The result of this research shows that the increased in social skills and the students learning outcomes in cycle I with a good criteria and increased to very good on the cycle II. The increase also occurred in the implementation of learning by teachers and students on the each cycle.
\end{abstract}

ABSTRAK

\begin{abstract}
Abstrak: Tujuan penelitian ini untuk mendeskripsikan penerapan model $F N P$ dan $I O C$ untuk meningkatkan keterampilan sosial dan hasil belajar siswa kelas IV SDN 3 Besuki. Jenis penelitian PTK meliputi dua siklus. Penelitian dilakukan di SDN 3 Besuki, subjek penelitian siswa kelas IV berjumlah 32 orang. Pengumpulan data, meliputi observasi, wawancara, tes, angket, dan dokumentasi. Teknik analisis data, meliputi reduksi, penyajian data, dan penarikan kesimpulan. Hasil pemelitian menunjukkan terjadinya peningkatan keteranpilan sosial dan hasil belajar siswa siklus I dengan kriteria baik dan meningkat menjadi sangat baik pada siklus II. Peningkatan juga terjadi pada pelaksanaan pembelajaran oleh guru dan siswa pada masing-masing siklus.
\end{abstract}

\author{
Alamat Korespondensi: \\ Anita Nurgufriani \\ Pendidikan Dasar \\ Universitas Negeri Malang \\ Jalan Semarang 5 Malang \\ E-mail: anitafriyani@gmail.com
}

Kurikulum 2013 merupakan kurikulum yang diterapkan di sekolah dasar saat ini dengan menggunakan, pendekatan penbelajaran tenatik terpadu. Penerapan pembelajaran tematik terpadu yang diterapkan di sekolah dasar merupakan upaya pemerintah dalam meningkatkan kualitas pendidikan ke arah yang lebih baik dan disamakan dengan kebutuhan maupun perkembangan yang berlaku pada saat ini. Pembelajaran tematik menganjurkan keleluasaan pada siswa untuk bisa mencari dengan sendirinya wawasan dalam berbagai informasi yang telah dipelajari (Permendikbud, 2013). Sebagaimana dipaparkan oleh Slavin (2005) pembelajaran kooperatif ialah pembelajaran yang mengajak siswa untuk belajar bersama-sama, saling menyumbangkan ide-idenya dan dapat bertanggung jawab terhdap hasil belajarnya.

Hasil observasi awal yang dilakukan di SDN 3 Besuki dengan melakukan wawancara kepada guru kelas IV, permasalahan yang ditemukan, meliputi (1) guru hanya menggunakan metode ceramah belum pernah menggunakan model pada saat pembelajarannya, (2) ada beberapa siswa pada masing-masing kelompok yang hanya mengandalkan temannya yang rajin untuk mengerjakan tugas, (3) siswa kurang berpartisipasi aktif dalam kegiatan diskusi, (4) interaksi antar siswa maupun dengan anggota kelompoknya tergolong rendah, kebanyakan siswa tidak memberikan perhatiannya pada siswa lain yang melakukan presentasi di depan kelas dan selalu asyik main sendiri, dan (5) hasil belajarnya berada pada tahap rendah.

Berdasarkan permasalahan tersebut, apabila terus-menerus terjadi maka akan memengaruhi hasil belajarnya ke depan. Sehingga langkah yang dapat dilakukan untuk mengurangi permasalahan tersebut yaitu dengan diterapkannya model Fan- $N$-Pick (FNP) dan Inside-Outside Circle (IOC). Kagan \& Kagan (2009) merupakan pengembang dari model FNP dan IOC, sebagaimana diketahui the learning model FNP is a cooperativ learming model where students in one group plays card game to respond to the questions, each student shifts roles with new questions. Disamping itu, model pembelajaran FNP berfungsi untuk membentuk kelompok, memungkinkan siswa terampil dalam bersosialisasi, membangun pemahaman sendiri maupun kemampuannya dalam 
berpikir (Kagan \& Kagan, 2009). Model IOC termasuk salah satu model pembelajaran kooperatif yang memberikan kesempatan kepada siswa untuk belajar sambil bermain, dimana model ini dalam penerapannya siswa dibagi dalam dua kelompok yang membentuk lingkaran yaitu sebagian siswa berada pada lingkaran luar dan sebagiannya lagi pada lingkaran dalam. Siswa pada lingkaran dalam berpasangan dengn siswa yang berada di lingkaran luar. Keunggulan yang dimiliki model ini yaitu mempunyai susunan atau urutan yang jelas sehingga memungkinkan siswa dapat saling bertukar pengetahuan yang diketahui kepada pasangannya dengan waktu yang singkat dan teratur (Wati, 2016). Kedua model ini memiliki kesamaan yaitu menggunakan kartu soal sebagai media belajar, pembelajaran berkelompok yang berpasang-pasangan dalam menyampaikan informasi, dan dapat menumbuhkan keterampilan sosial.

Keterampilan sosial sangat dibutuhkan dalam bekerja sama maupun interaksi dengan individu lain. Sebagaimana dipaparkan oleh (Arends, 2004) keterampilan sosial merupakan sikap yang dapat mendukung seseorang dalam menciptakan keberhasilan dalam hubungan sosial dengan individu lain yang memungkinkannya dalam melakukan kerjasama. Dimana dalam pembelajaran di kelas, model FNP maupun IOC dapat memfasilitasi siswa untuk berbagi pengetahuan yang dimilikinya kepada satu sama lain dengan tujuan bertukar informasi yang berdasar pada bahan yang telah dipelajarinya. Keterampilan sosial sangatlah relevan dalam hubungan bersosialisasi dengan oorang lain dan akan berguna dalam bekerjasama secara efektif satu sama lainnya. Siswa dengan keterampilan sosial yang baik dapat memberikan dampak yang baik pada hasil belajarnya kedepan. Perubahan sikap dan tindakan pada setiap individu menunjukkan sebagai hasil belajar. Hasil belajar berkaitan dengan pemenuhan untuk mendapatkan pengetahuan sesuai dengan tujuan khusus yang telah rencanakan (Sanjaya, 2009). Perolehan hasil belajar dapat diketahui setelah perubahan yang ditunjukkan oleh masing-masing individu baik dari segi pemahaman, pengetahuannya, sikap yang ditunjukkan maupun keterampilan siswa menunjukan adanya tahap peningkatan.

Penelitian terdahulu yang mendukung penelitian ini yaitu berdasarkan pada penelitian oleh Riyadi, dkk (2016) dengan judul The Implementation of Cooperative Learnig Model FNP and Quick on the Draw to Enchance Sosial Competence and Cognitive Learning Outcome for Social Study didapatkan hasil bahwa keterampilan sosial siswa dan hasil belajar IPS menunjukkan kenaikan pada masing-masing siklus. Penelitian lain dilakukan oleh Habidi, dkk (2017) dengan judul The Implementation of Coperative Lerning Model QQT \& IOC to Improve the Students Communicative Skill and Learning on Social Science Lesson dapat meningkatkan keterampilan berkomunikasi \& hasil belajar siswa. Penelitian serupa juga dilakukan Frianto, dkk (2016) yaitu The Implementation of Cooperative Learning Model TGT \& FNP to Enhance Motivation and Social Studies Learning Outcomes mengalami peningkatan baik pada motivasi maupun hasil belajar. Penelitian sebelumnya yang dilakukan Ningsih \& Andriani (2017) melalui Pnerapan Model Pembelajaram Inside Outside Circle terhadap Kemampuan Pemahaman Konsep Siswa, kemampuan pemahaman konsep matematika siswa mengalami kenaikan atau meningkat di kelas VIII Sekolah Menengah Pertama Negeri 3 Sungai Lala.

Permasalahan yang melatarbelakangi penelitian ini adalah (1) bagaimana penerapan model FNP dalam meningkatkan keterampilan sosial \& hasil belajar siswa, (2) bagaimana penerapan model IOC dalam meningkatkan keterampilan sosial dan hasil belajar, dan (3) bagaimana peningkatan keterampilan sosial dan hasil belajar siswa kelas IV SDN 3 Besuki melalui penerapan model FNP dan IOC.

\section{METODE}

Penelitian ini menggunakaan rancangan penelitian tindakaan kelas. Sebagaimana dikemukakan oleh Sanjaya (2015) classroom action research ialah salah satu upaya guru dalam meningkatkan kualitas dan peran maupun tanggung jawabnya terlebih dalam merencanakan skenario pembelajaran. Pada penelitian ini, kehadiran peneliti di lapangan yaitu sebagai pengumpul data dan pelaksana tindakan di kelas pada saat proses kegiatan belajar mengajar di kelas. Pengajaran dilakukan oleh peneliti sendiri serta bertindak sebagai penyusun perencanaan pembelajaran, melaksanakan perencanaan pembelajaran, mengumpulkan data, menganalisa data dan melaporkan hasil penelitian. Siswa kelas IV SDN 3 Besuki dengan jumlah 32 siswa dengan 14 siswa laki-laki dan 18 siswa perempuan merupakan subjek penelitiannya. Adapun data yang akan dikumpulkan yaitu data hasil observasi terkait (1) keterlaksanaan pembelajaran oleh siswa dan guru melalui panerapan model pembelajaran FNP serta model IOC, (2) keterampilan sosial siswa selama proses pembelajaran dengan menerapkan model FNP dan IOC, dan (3) hasil belajar setelah mengikuti pembelajaran. Adapun data lainnya sebagai penunjang penelitian, yaitu RPP, kartu soal, dan daftar nilai hasil belajar siswa. Pengumpulan data terdiri dari observasi, wawancara, tes, angket (kuesioner), dan dokumentasi. Teknik analisis datanya ialah dengan analisis data deskriptif di mana analisis data yang dilakukan secara interaktif peran sampai tuntas. Penerapan teknik analisis deskriptif menurut Miles \& Huberman (dalam Sugiyono, 2016) terdiri atas (1) reduksi data, (2) penyajian data, dan (3) penarikan kesimpulan.

\section{HASIL}

Pelaksanaan tindakan dalam penelitian ini dilakukan dengan penerapan model FNP dan IOC dengan menggunakan pembelajaran tematik di kelas IV SDN 3 Besuki. Hasil penelitian terlaksana dengan sangat baik sesuai dengan perbaikan pembelajaran yang telah dilakukan pada pembelajaran sebelumnya. Pelaksanaan penelitian ini menggunakan dua siklus, meliputi siklus I dan siklus II yang terdiri dari lima kali pertemuan dan pada pertemuan kelima digunakan untuk mengisi angket (kuesioner). Data hasil analisis tindakan yang dipaparkan, meliputi (a) penerapan model FNP dan IOC dalam pembelajaran tematik, (b) penerapan model pembelajaran FNP dan IOC dalam meningkatkan keterampilan sosial siswa, dan (c) penerapan model 
pembelajaran FNP dan IOC dalam meningkatkan hasil belajar. Penerapan model FNP dan IOC dalam pembelajaran tematik, mencakup data keterlaksanaan pembelajaran yang dilakukan oleh siswa dan guru. Data hasil analisis observasi keterlaksanaan pembelajaran oleh siswa dan guru pada masing-masing siklus mengalami peningkatan. Hal ini diketahui berdasarkan data observasi keterlaksanaan pembelajaran oleh siswa dan guru seperti pada sajian tabel 1.

Tabel 1. Keterlaksanaan Pembalajaran oleh Guru dan Siswa Siklus I \& II

\begin{tabular}{|c|c|c|c|c|c|c|c|c|c|}
\hline \multirow[t]{3}{*}{ Kegiatan } & \multirow[t]{3}{*}{ Skor Maksimal } & \multicolumn{4}{|c|}{ Pelaksanaan Pembelajaran oleh Guru } & \multicolumn{4}{|c|}{ Pelaksanaan Pembelajaran oleh Siswa } \\
\hline & & \multicolumn{2}{|c|}{$\begin{array}{c}\text { Siklus I } \\
\text { Observer }\end{array}$} & \multicolumn{2}{|c|}{$\begin{array}{l}\text { Siklus II } \\
\text { Observer }\end{array}$} & \multicolumn{2}{|c|}{$\begin{array}{c}\text { Siklus I } \\
\text { Observer }\end{array}$} & \multicolumn{2}{|c|}{$\begin{array}{l}\text { Siklus II } \\
\text { Observer }\end{array}$} \\
\hline & & I & II & $\mathbf{I}$ & II & I & II & I & II \\
\hline Pendahuluan & 12 & 8 & 8 & 11 & 10 & 10 & 8 & 11 & 10 \\
\hline Inti & 36 & 30 & 28 & 32 & 33 & 28 & 25 & 30 & 33 \\
\hline Penutup & 12 & 8 & 12 & 10 & 11 & 7 & 9 & 10 & 10 \\
\hline \multirow[t]{4}{*}{ Jumlah Skor } & 60 & 46 & 48 & 53 & 54 & 45 & 42 & 51 & 53 \\
\hline & Persentase Rata-rata Skor & $76,66 \%$ & $80 \%$ & $88,33 \%$ & $90 \%$ & $75 \%$ & $70 \%$ & $85 \%$ & $88,33 \%$ \\
\hline & Persentase Akhir & \multicolumn{2}{|c|}{$78,33 \%$} & \multicolumn{2}{|c|}{$89,16 \%$} & \multicolumn{2}{|c|}{$72,5 \%$} & \multicolumn{2}{|c|}{$86,66 \%$} \\
\hline & Peningkatan & & & & & & & & \\
\hline
\end{tabular}

Data yang ditunjukkan pada tabel 1 hasil keterlaksanaan pembelajaran yang dilakukan oleh guru dan siswa dengan menerapkan model FNP dan IOC pada pembelajaran tematik menunjukkan adanya peningkatan. Peningkatan hasil pelaksanaan pembelajaran yang dilakukan oleh guru pada siklus I sebesar $78,33 \%$ dan yaitu $(\geq 80 \%)$. Dengan demikian, melalui penerapan model FNP dan IOC, maka keterampilan sosial siswa menunjukkan meningkat menjadi $89,16 \%$ dan siklus II dengan indeks kenaikan $10,83 \%$. Keterlaksanaan pelaksanaan pembelajaran oleh siswa pada siklus I yakni sebesar $72,5 \%$ dan meningkat kembali menjadi 86,66\% untuk siklus II, dari kedua siklus tersebut dengan persentase sebanyak 14,16\%. Berdasarkan hasil rekapitulasi, keterlaksanan pembelajaran oleh siswa dan guru menunjukkan telah mencapai target keberhasilan hasil yang lebih baik.

Peningkatan tidak hanya terjadi pada keterlaksanaan pembelajaran oleh siswa dan guru, melainkan juga pada observasi keterampilan sosial siswa. Ada lima aspek yang diamati dalam melakukan penilaian keterampilan sosial siswa, meliputi kerja sama, ketegasan, tanggung jawab, empati, dan pengendalian diri. Hasil observasi keterampilan sosial siswa dengan menerapkan model pembelajaran FNP dan IOC menunjukkan adanya peningkatan kedua siklus, jika dilihat dari hasil observasi selama kegiatan belajar mengajar berlangsung maupun dengan pemberian angket (kuesioner), sebagaimana ditunjukkan pada gambar 1 .

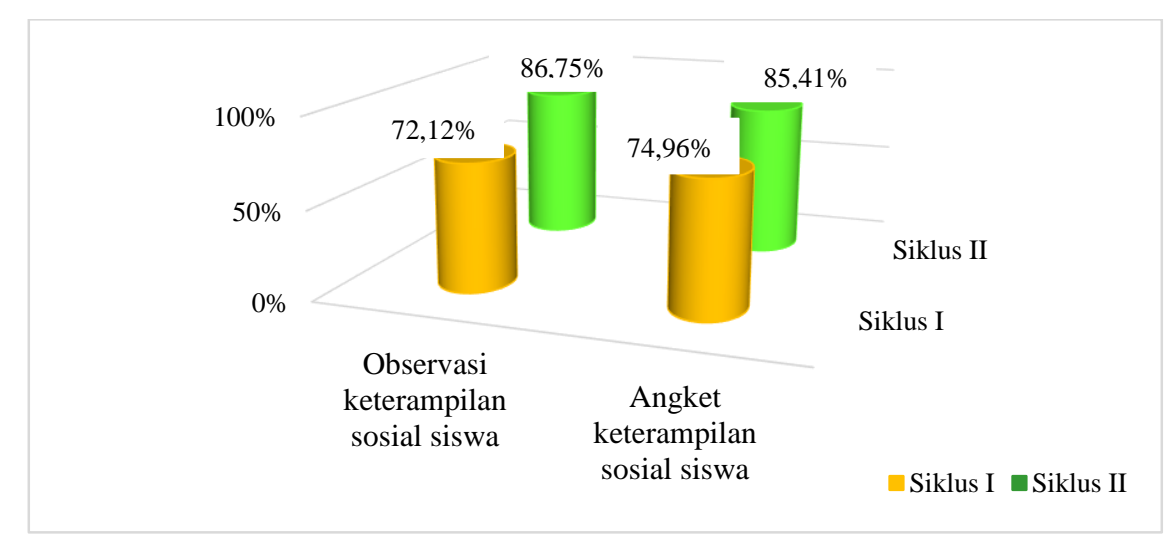

\section{Gambar 1. Hasil Observasi dan Angket Keterampilan Sosial Siswa}

Data yang ditunjukkan gambar 1 berdasarkan temuan hasil observasi dan angket keterampilan sosial siswa melalui penerapan model FNP dan IOC terlihat jelas bahwa hasil persentase menunjukkan adanya peningkatan pada masing-masing silusnya. Hasil observasi keterampilan sosial siswa siklus I ialah 72,12\% dan pada siklus II mencapai persentase $86,75 \%$ dengan kenaikan yakni 14,63\%. Hasil angket keterampilan sosial siswa menunjukkan peningkatan sebesar 74,96\% pada siklus I menjadi $85,41 \%$ pada siklus II, dengan jumlah peningkatan 10,45\%. Dengan demikian, hasil rekapitulasi menunjukkan patokan keberhasilan yakni $\geq 80 \%$. Berdasarkan paparan data tersebut, didapati bahwa dengan menerapkan model FNP maupun IOC dapat meningkatkan keterampilan sosial siswa. Hasil belajar siswa menunjukkan adanya peningkatan dengan dilakukannya penerapan model FNP dan IOC. Hal ini berdasarkan nilai yang diperoleh siswa dari data pra siklus, tes akhir siklus I dan II, sebagaimana disajikan pada gambar 2 . 


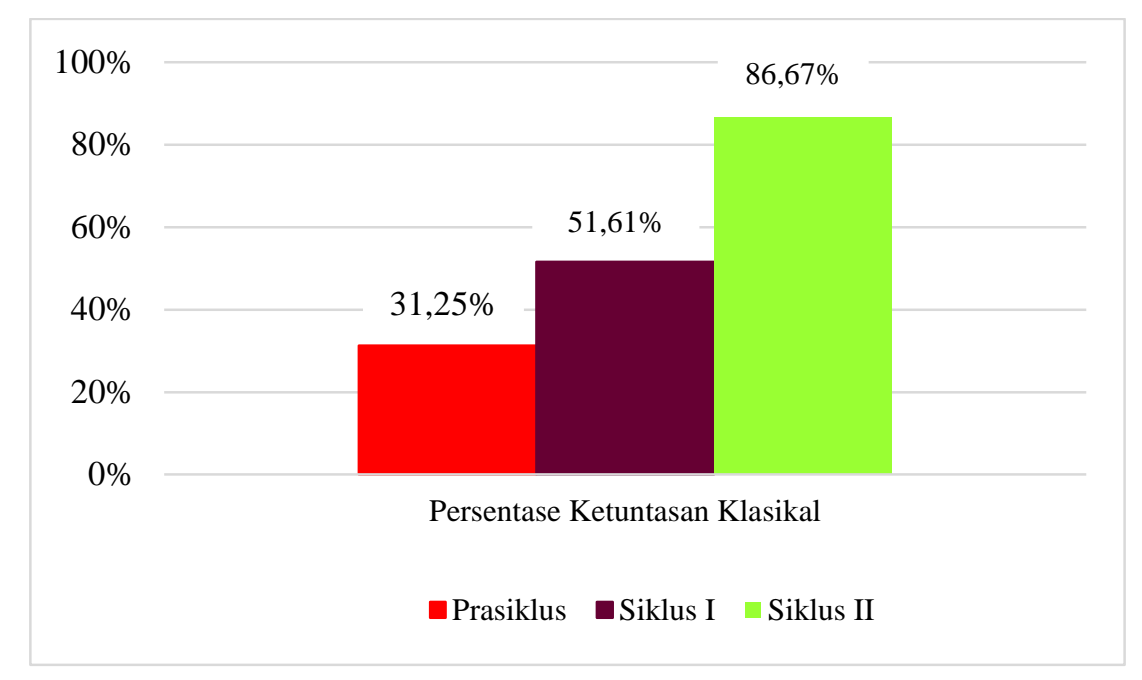

\section{Gambar 2. Hasil Belajar Kognitif Siswa (Pra Siklus, Siklus I, dan Siklus II)}

Berdasarkan tabel 1 dan gambar 2 temuan penelitian hasil belajar kognitif siswa melalui penerpan model Fan- $N$-Pick dan Inside-Outside Circle pada pra siklus, siklus I maupun siklus II menunjukkan adanya peningkatan pada masing-masing siklus. Data ketuntasan klasikal pra siklus sebesar 31,25\% dan 51,61\% pada siklus I dengan jumlah peningkatan sebanyak 20,36\%, sedangkan pada siklus II mengalami peningkatan sebesar 86,67\% dengan jumlah peningkatan sebesar 35,06\%. Dengan demikian, hasil persentase pada siklus II sudah mencapaikriteria keberhasilam tindakan yang diharapkan. Berdasarkan hasil rekapitulasi hasil belajar dengan menerapkan model FNP dan IOC menunjukkan telah mencapai krtieria keberhasilan tindakan $\geq 80 \%$. Dengan demikian, hasil belajar siswa menunjukkan kenaikan dengan diterapkannya model FNP dan IOC dalam pembelajaran.

\section{PEMBAHASAN}

Penerapa model pembelajran FNP dan IOC pada kelas IV di SDN 3 Besuki dilakukan melalui dua siklus, yakni siklus I dan II data hasil tindakan menunjukkan keterampilan sosial dan hasil balajar siswa mengalami peningkatan. Pelaksanaan pembelajaran telah memberikan dampak yang positif. Hasil analisis data yang dilakukan peneliti, antara lain (a) penerapan model FNP dan IOC dalam pembelajaran tematik, (b) penerapan model FNP dan IOC menunjukkan kenaikan pada keterampilan sosial siswa, dan (c) penerapan model pembelajaran FNP dan IOC menunjukkan adanya peningkatan pada hasil belajar siswa.

Penerapan model FNP dan IOC dalam pembelajaran tematik berdasarkan hasil observasi selama proses pembelajaran berlangsung, menunjukkan adanya peningkatan. Hal in diketahui dengan data yang didapat pada siklus I bahwa observasi pelaksanaan pembelajaran oleh guru menunjukkan perolehan sebanyak 78,33\% jika dikonversikan maka termasuk dalam kriteria "baik". Hasil tersebut mengalami peningkatan sebanyak 10,83\% pada siklus II yakni menjadi 89,16\% dengan kriteria "sangat baik". Sementara itu, data hasil pelaksanaan pembelajaran yang dilakukan oleh siswa menunjukkan perolehan se besar $72,5 \%$ pada siklus I jika dikonversikan maka termasuk dalam kriteria "baik", hasil tersebut mengalami kenaikan sebesar, 14,16\% menjadi 86,66\% pada siklus II. Hasil penelitian ini berdasar pada beberapa penelitian terdahulu, seperti yang dilakukan Radja, dkk (2017) peningkatan juga terjadi pada keterlaksanaan pembelajaran oleh siswa \& guru. Penelitian lain dilakukan Nurdianasari, dkk (2017) bahwa data observasi pelaksanaan pembelajaran by teacher in cycle I showed that the acquisition of 81,40\% has increased by $3,85 \%$ in cycle II, that is $85,25 \%$ sedangkan pelaksanaan pembelajaran oleh siswa yaitu $82,09 \%$ experienced an increase of $3.91 \%$ to $86 \%$ in cycle II. Berdasarkan data hasil observasi tersebut, dapat diketahuibahwa melalui penerapan model FNP dan IOC dapat meningkatkan pelaksanaan pembelajaran baik oleh guru maupun siswa.

Pada penelitian ini, ada lima aspek atau indikator keterampilan sosial yang diamati, meliputi kerja sama, ketegasan, tanggung jawab, empati, dan pengendalian diri. Kelima indikator tersebut merupakan indikator keterampilan sosial yang dikemukakan oleh Gresham, at al (2010). Instrumen yang digunakan untuk mengetahui keterampilan sosial siswa kelas IV SDN 3 Besuki yaitu menggunakan lembar observasi dan angket. Observasi keterampilan sosial siswa dilakukan dengan menggunakan lembar obsrevasi, sedangkan angket digunakan sebagai self report (laporan mandiri) yang memuat 40 butir pertanyaan yang memuat kelima indikator keterampilan sosial.

Keterampilan sosial siswa mengalami peningkatan selama pembelajaran dengan model FNP dan IOC. HaI ini dapat ditunjukkan melalui hasil observasi keterampilan sosial siswa pada saat kegiatan pembelajaran berlangsung. Adapun perolehan skor hasil analisis pengamatan keterampilan sosial siswas tersebut yaitu 72,12\% pada siklus I dan mengalami kenaikan pada siklus II 86,75\% dengan persentase 14,63\%. Hasil angket keterampilan sosial siswa menunjukkan persentase sebesar 74,96\% pada siklus I dan meningkat menjadi $85,41 \%$ untuk siklus II dengan persentase $10,45 \%$. Membangun pembelajaran terkait keterampilan sosial di sekolah dapat meningkatkan kemampuan belajar siswa serta adanya hubungan baik antara anak dan orang 
lain. Sebagaimana diketahui dari hasil penelitian sebelumnya oleh Purwaningrum, dkk (2017) nilai rata-rata observasi keterampilan sosial siswa in cycle 1 was $74 \%$ which is classified as good criteria and has yet fulfilled the success criteria which are $80 \%$. In the cycle 2, the average value of student learning implementation of $83,83 \%$ dengan kriteria sangat baik. Didapati bahwa dengan menerapkan model FNP dan IOC keterampilan sosial siswa mengalami peningkatan. Melalui hasil observasi dan angket keterampilan sosial pada kedua siklus tersebut menunjukkan bahwa penerapan model FNP dan IOC pada keterampilan sosial siswa kelas IV SD Neg 3 Besuki menunjukkan adanya peningkatan.

Pengukuran hasil belajar diukur menggunakan instrumen yakni berupa tes. Tes dilaksanakan pada pertemuan kelima yaitu pada akhir siklus. Soal tes terdiri dari pilihan ganda 10 soal, 10 soal isian, dan 10 soal uraian sehingga jumlah soal secara keseluruhannya sebanyak 30 soal. Pembuatan soal disesuaikan dengan tingkatan ranah kognitif C1—C5, dimana soal tes siklus I mengacu pada materi tema 7 "Indahnya Keragaman di Negeriku" sub tema 3 "Indahnya Persatuan dan Kesatuan Negeriku", sedangkan siklus II mengacu pada mataeri tema 8 "Daerah Tempat Tinggalku" sub tema 3 "Bangga terhadap Daerah Tempat Tinggalku". Pada saat penyusunan soal tes, diperlukan pula kunci jawaban beserta pedoman penskorannya. Hasil penelitian melalui model pembelajaran FNP dan IOC pada pembelajaran tematik menunjukkan bahwa model tersebut meningkatkan hasil belajar siswa kelas IV SDN 3 Besuki. Data pada pra siklus menunjukkan sebanyak 10 berada pada kategori tuntas, siklus I mengalami kenaikan sebanyak 16 siswa dan mengalami peningkatan sebanyak 26 siswa untuk siklus II.

Berdasarkan hasil analisis ketuntasan belajar siswa pada pra siklus yaitu sebesar 31,25\% menjadi 51,61\% siklus I mengalami kenaikan $86,67 \%$ siklus II dengan peningkatan sebanyak 20,36\% pada pra siklus ke siklus I, sedangkan pada siklus I dan II terjadi kenaikan sebesar 35,06\%. Sama halnya dengan penelitian yang dilakukan oleh Barsihanor (2016) mengenai penerapan model pembelajaran cooperatif learning teknik IOC terhadap hasil belajar siswa di MI Darul Mujahidin, didapatkan hasil bahwa berdasarkan Uji Parsial, diketahui bahwa nilai signifikansi sebesar $0,004<0,05$, diketahui bahwa Ho ditolak Penelitian lain yang dilakukan oleh Lusiana, dkk (2017) didapatkan hasil bahwa penelitian dengan model TSTS and FNP learning models can improve students cognitive learning outcomes in social studies subject of class IV of SD Negeri Tawun I Ngawi. Hasil penelitian melalui penerapan model FNP dan IOC keterampilan sosial dan hasil belajar siswa menunjukkan adanya peningkatan pada masing-masing siklus dan mencapai target keberhasilan tindakan yang ditetapkan yaitu $\geq 80 \%$.

\section{SIMPULAN}

Model pembelajaran Fan-N-Pick (FNP) dan Inside-Outside-Circle (IOC) dapat meningkatkan keterampilan sosial \& hasil belajar siswa kelas IV SDN 3 Besuki. Hal ini dibuktikan dengan penerapan model FNP dan IOC dalam pembelajaran tematik didapatkan hasil bahwa dalam pelaksanaan pembelajaran oleh gruu pada siklus I dengan 78,33\% menjadi $89,16 \%$ pada siklus II, sedangkan keterlaksanaan pembelajaran oleh siswa pada siklus I sebesar 72,5\% menjadi 86,66\% pada siklus II, dengan peningkatan $14,16 \%$. Kemudian hasil keterampilan sosial siswa pada siklus I menunjukkan peningkatan $72,12 \%$ menjadi $86,75 \%$ pada siklus II dengan persentase peningkatan $14,63 \%$, sedangkan hasil angket keterampilan sosial siswa pada siklus I menunjukkan kenaikan sebesar $74,96 \%$ dan $85,41 \%$ pada siklus II, dengan jumlah peningkatan $10,45 \%$. Penerapan model pembelajaran FNP dan IOC dapat meningkatkan hasil belajar, hal ini diketahui dengan ketuntasan klasikal pra siklus yakni sebesar $31,25 \%$ dan $51,61 \%$ pada siklus I dengan jumlah peningkatan $20,36 \%$, sedangkan pada siklus II mengalami peningkatan kembali menjadi $86,67 \%$ dengan jumlah peningkatan 35,06\%. Dengan mencapai kriteria keberhasilan $\geq 80 \%$ maka penerapan model Fan$\mathrm{N}$-Pick dan Inside-Outside Circle dalam pembelajaran tematik dapat meningkatkan keterampilan sosial dan hasil belajar.

\section{DAFTAR RUJUKAN}

Arends. (2004). Belajar dan Pembelajaran. Jakarta: Rineka Cipta.

Frianto., Soetjipto, B. E., \& Amirudin, A. (2016). The Implementation of Cooperative Learning Model Team Game

Tournament and Fan N Pick to Enhance Motivation and Social Studies Learning Outcomes. IOSR Journal of Humanities and Social Science, 21(5), 74-81. https://doi.org/10.9790/0837-2105077481.

Gresham, M. F., \& Elliot, S. N \& Cook, C. R., Vance, M. J., \& Kettler, R. (2010). Cross-Informant Agreement for Ratings for Social Skill and Problem Behavior Ratings: An Investigation of the Social Skills Improvement System-Rating Scales. Psychological Assessment, 22(1), 157-166. https://doi.org/10.1037/a0018124.

Habidi, Widiati, U., \& Soetjipto, B. E. (2017). The Implementation of Cooperative Learning Model Quiz-Quiz Trade and Inside-Outside Circle to Improve the Students' Communicative Skill and Learning on Social Science Lesson. IOSR Journal of Humanities and Social Science, 22(4), 61-69. https://doi.org/10.9790/0837-2204016169.

Kagan, S., \& Kagan, M. 2009. Kagan Cooperative Learning. San Clemente: Kagan Publishing.

Lusiana, A. I., Setyosari, P., \& Soetjipto, B. E. (2017). The Application of Two Stay Two Stray (TSTS) and Fan-N-Pick Learning Models to Improve Students Motivation and Learning Outcomes on Social Studies Subject (A Study on the Fourth Grade students of SDN Tawun I Ngawi). International Journal of Academic Research in Progressive Education and Development, 6(3). https://doi.org/10.6007/ijarped/v6-i3/3138.

Ningsih, Y \& Andriani, S. 2017. Penerapan Model Pembelajaran Inside Outside Circle terhadap Kemampuan Pemahaman Konsep Siswa. 2(2), 1-10.

Nurdianasari, N., Hanurawan, F., \& Soetjipto, B. E. (2017). The Implementation of Quiz-Quiz-Trade and Fan-N-Pick Learning Model to Enhance Social Skills and Cognitive Learning Outcome of Social Studies. 6(6), 81-85. 
Permendikbud. (2013). Menteri Pendidikan dan Kebudayaan Republik Indonesia. Jakarta: Kemendikbud.

Purwaningrum, D., Soetjipto, B. E., \& Untari, S. (2017). The Implementation of Cooperative Learning Model Quiz-Quiz Trade and Inside-Outside Circle to Improve the Students' Social Skills and Learning Outcomes. IOSR Journal of Humanities and Social Science, 22(4), 61-69. https://doi.org/10.9790/0837-2204016169.

Radja, L. P., Soetjipto, B. E., \& Amirudin, A. (2017). Implementasi Model Pembelajaran Kooperatif Talking Chips dan Fan-NPick dalam Meningkatkan Motivasi dan Hasil Belajar IPS. Jurnal Pendidikan: Teori, Penelitian, dan Pengembangan, 2(1), 1196-1201.

Riyadi, A., Soetjipto, B. E., \& Amirudin, A. (2016). The Implementation of Cooperative Learning Model Fan-N-Pick and Quick on the Draw to Enhance Social Competence and Cognitive Learning Outcome for Social Studies. IOSR Journal of Humanities and Social Science, 21(4), 90-96. https://doi.org/10.9790/0837-2104019096.

Sanjaya, W. (2009). Perencanaan dan Desain Sistem Pembelajaran. Jakarta: Kencana.

Sanjaya, W. (2015). Penelitian Tindakan Kelas. Jakarta: Prenadamedia Group.

Slavin, R. (2005). Cooperative Learning: Teori, Riset, dan Praktik. Bandung: Nusa Media.

Sugiyono. (2016). Metode Penelitian Pendidikan Pendekatan Kuantitatif, Kualitatif, dan R \& D. Bandung: Alfabeta.

Wati, M. (2016). Penerapan Model Pembelajaran Kooperatif Tipe Inside Outside Circle pada Pembelajaran Matematika Siswa Kelas VIII SMP Negeri 9 Pariaman. 3(1), 1-5. 